\title{
A new portable ice-core drilling machine: application to tephra studies
}

\author{
J. M. Casas, ${ }^{1}$ F. Sàbat, ${ }^{1}$ J. M. Vilaplana, ${ }^{1}$ J.M. Parés, ${ }^{2}$ D. M. Pomeroy ${ }^{3}$ \\ ${ }^{1}$ Departament de Geologia Dinàmica, Geofísica i Paleontologia, Universitat de Barcelona, Martí Franquès s/n, E-08071 Barcelona, Spain \\ ${ }^{2}$ Institut de Ciències de la Terra Jaume Almera, CSIC, Marti Franquès s/ $n$, E-08071 Barcelona, Spain \\ ${ }^{3}$ Pomeroy Industries Unlimited, Menlo Park, California 94025, U.S.A.
}

\begin{abstract}
A new portable device for ice-core drilling, specially designed for thin tephra-layer sampling, was tested on the South Shetland glaciers during the 1994-95 Antarctic summer. The machine is based on a combination of the standard paleomagnetism drilling machine and a specially built drill-bit designed for ice-coring.
\end{abstract}

\section{INTRODUCTION}

Vertical ice-core drilling, a glaciological technique developed in order to obtain a continuous record of ice layers at various depths, is an important methodology for use in vertical holes. In contrast, the technology available to perform horizontal or non-vertical ice-core drilling is much more restricted. Manual sampling using a small drilling machine (e.g. $20 \mathrm{~cm}$ long and $5 \mathrm{~cm}$ diameter samples) seems to be the only available option.

Part of our work on Livingston Island $\left(62^{\circ} 39^{\prime} \mathrm{S}\right.$, $60^{\circ} 23^{\prime} \mathrm{W}$; South Shetlands, Antarctica) is devoted to study of Holocene volcanic ashes interlayered in the Livingston ice sheets (Fig. la and b). The ashes constitute an excellent marker of the internal structure and stratigraphy of the ice and, when dated, provide valuable information about ice age, mass balance, ice kinematics (Calvet and others, 1993) and recent volcanic activity (Smellie, in press). Tephra layers on Livingston Island form thin levels, $0.5-2 \mathrm{~cm}$ thick; these layers are well exposed on ice cliffs, crevasses, snow fosses and occasionally in ablation ramps when snow-free (Fig. lc). Their thickness and the peculiar outcropping conditions make sampling procedure a key problem in the tephra studies. To solve this problem, i.e. to obtain easily a sufficient amount of sample, we have developed a portable ice-boring, motor-driven machine. We need to obtain a large number of horizontal or inclined cores in a short time from steep slopes or vertical cliffs. Thus, we need a powerful, lightweight and easy-to-use tool. The prototype was tested during the 1994-95 Antarctic summer expedition. Our purpose in this paper is to characterize the prototype and its applicability to ice sampling.

\section{DESIGN}

Our goal was to obtain a portable drilling machine with all of the following requirements: self-powered, easy to use even in extreme conditions, efficient and strong.

Our idea was to adapt rock-sampling machines to ice. So we developed an ice-boring machine composed of an ice bit and a separate core-drill power head (Fig. ld). The ice bit is similar to those used in manual, vertical ice-coring and consists of three pieces: the crown, the tube and the drive nut. After several trials with different types of crown, we chose one that is formed by a $9 \mathrm{~cm}$ inner diameter aluminum ring holding three carbide teeth with a cutting angle of $80^{\circ}$. The aluminum tube is $46 \mathrm{~cm}$ long, with four big spiral flutes making a pitch of $45^{\circ}$, and holes in the top. Two of these flutes run the whole length of the tube, whereas the other two run halfway up the tube. The drill-bit was made by Pomeroy. The drive nut joins the tube to the power head. We used the Pomeroy DO26-GT10 model power head which is furnished with a STIHL $48 \mathrm{cc}$ gasoline motor, developing 3.5 h.p. $(2.6 \mathrm{kw})$ at $10000 \mathrm{rpm}$. This model seemed to be adequate to turn the big bit, even full of ice, while providing an acceptable drilling rate. This machine is geared down at approximately $5: 1$. The total weight of the engine, empty drill-bit and adapter is about $6 \mathrm{~kg}$.

\section{FIELD TEST}

During the 1994-95 Antarctic summer we sampled 21 sites distributed in six localities on Livingston Island (Fig. 1b). Three of these localities were on ice cliffs, and the others in a wind fosse, a crevasse and an ablation ramp.

Details on the sampled ash layers are found in Calvet and others (1993). We can briefly summarize the tephra stratigraphy as follows. Tephra layers form three groups: (1) The upper group is formed by a thin single layer, with thickness ranging between a few millimeters and $2 \mathrm{~cm}$, and is recognizable in the eastern part of the island. This level has also been identified in some vertical cores from the accumulation zone. (2) The intermediate group appears to be a double layer, but close observations reveal that it corresponds to a $0.5 \mathrm{~cm}$ thick single layer. Despite its small thickness, it frequently appears as a characteristic feature of glacier ablation zones due to its folded disposition. (3) The lowest group is formed by at least five different layers, separated by $80-100 \mathrm{~cm}$ of ice, each layer having a thickness of $1-$ $1.5 \mathrm{~cm}$. This lowest group is present in all the studied Livingston ice cliffs (Fig. 1c). 

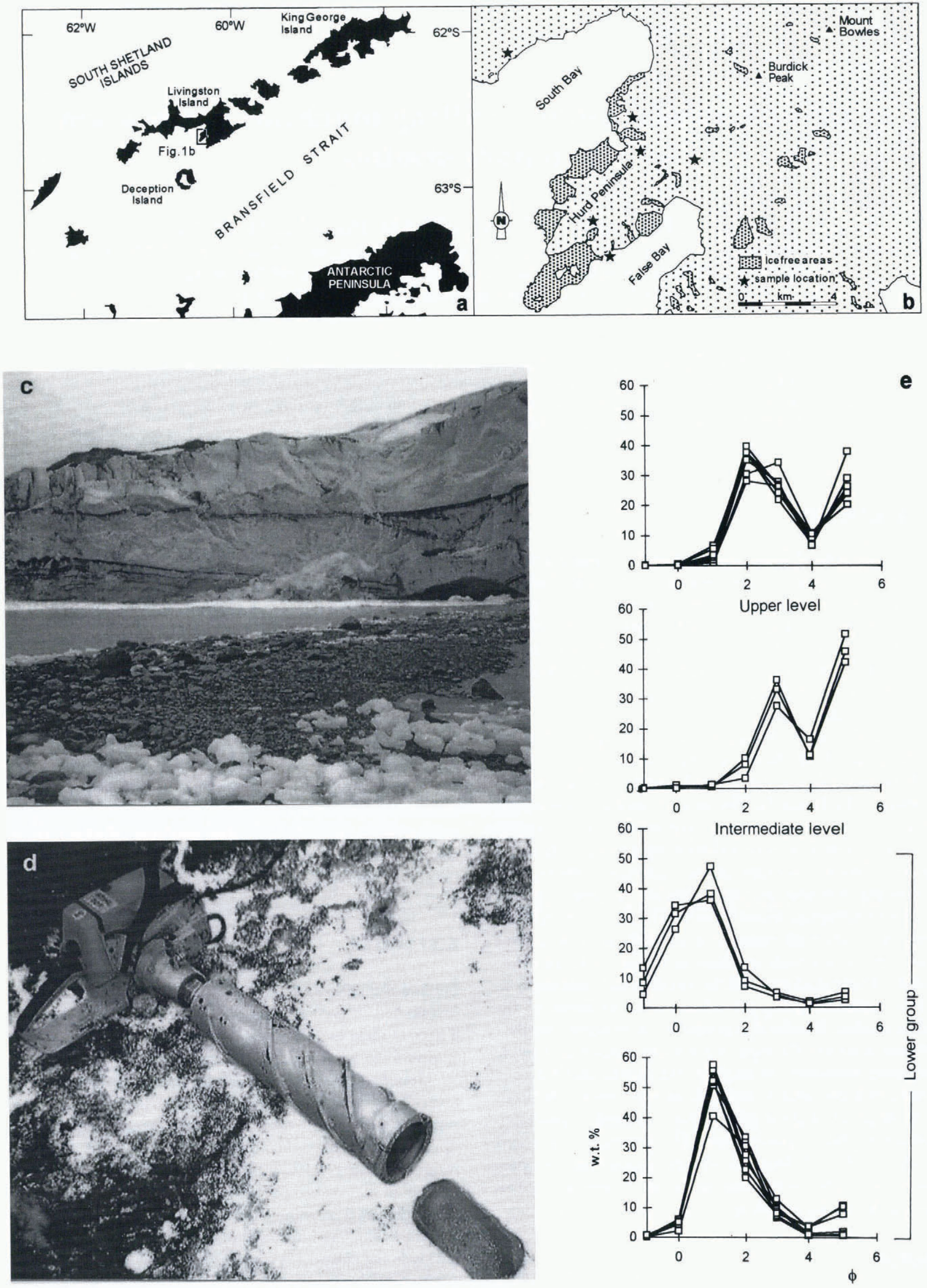

Fig. 1. (a) South Shetland Islands, showing the location of the sampled area on Livingston Island. (b) Location of the six localities sampled on Livingston Island. (c) Tephra layers exposed in an ice cliff. The layer recognizable in the middle of the cliff corresponds to the intermediate tephra group, whereas the lower group is well exposed near sea level. (d) The ice-boring machine, together with a fragment of an ice core containing a thin tephra layer. (e) Grain-size distribution of the Livingston tephras. 
During fieldwork, we sampled the above-described seven different ash layers at the 21 sites. At each site, we had to drill a variable number of ice cores until enough tephra was obtained. The amount of tephra in each core is variable, ranging from 15 to $200 \mathrm{~g}$ depending on the ash-layer thickness and grain-size. A total of $2.4 \mathrm{~kg}$ of ash was collected from these 21 sites.

The ice-boring machine works very well and is very efficient, cutting the ice at an approximate drilling rate of 30 $35 \mathrm{~cm} \mathrm{~min}^{-1}$, roughly equivalent to $1.5 \mathrm{~kg}$ ice $\min ^{-1}$. When the boring is finished, wrenching the drill sideways breaks off the core easily. Usually, the core comes out in one or two pieces, with a total length of $35-45 \mathrm{~cm}$. The core shows intact the original structure of the ice and ash layers, without disturbance from cutting, or ice chips.

Drilling on steep cliffs, where the operator is hanging from a rope, makes the sampling procedure more laborious. In this case, the drilling machine must be lowered to the bottom of the cliff in order to remove the ice core from the drill-bit, and then raised up to the sampling point again. This process is time-consuming and requires setting up an adequate system of ropes and miscellaneous climbing aids with the aim of optimizing all the drilling procedures.

The internal diameter of the cutter head is only $1.5 \mathrm{~mm}$ smaller than the core tube. This causes the core to become slightly stuck in the tube. This can be an advantage in preventing the ice cores from falling out when the drill machine is moved up and down along the cliff. Nevertheless, in some cases difficulties arise in removing the ice cores.

Another aspect to note is the fact that with this drilling machine it is easy to drill at different orientations. This flexibility, together with its elevated drilling rate, is very advantageous when sampling in ice outcrops where the real dip of tephra layers is not visible, with only apparent dips observed on the outcrop surface, for it is possible to do a lot of exploratory drilling until the appropriate drill orientation is determined.

\section{RESULTS}

The main goal of the sampling was to analyze different tephra layers in order to determine whether the layers differentiated and correlated on the basis of stratigraphic criteria show similar granulometric, morphometric and/or geochemical features. A secondary goal was to establish whether these features were specific enough to constitute a useful tool for correlating well-separated outcrops.

In a general sense, Livingston tephras display fine grainsize, ranging between -1 and $4 \phi$ (Fig. le). The most striking feature is that the three tephra groups exhibit slightly different, but recognizable, grain-size distribution. That is, the three groups are coherent granulometrically. The uppermost level is fine-grained, with predominant grain-size values of $2 \phi$. This level is attributed to the 1970 Deception Island volcanic eruption from regional (Calvet and others,
1993), radiometric (Pourchet and others, 1996) and geochemical data (work in progress). The intermediate layer furnished the finest grain-size, with values around $3 \phi$. The lowest group is the most heterogeneous, with grain-size ranging from -1 to $3 \phi$, although the different tephra levels are, in general, coarser.

Encouraged by these results, present work is dealing with geochemical fingerprinting of different tephra layers. This could be a useful correlation tool between Livingston tephra layers and historically dated tephras and volcanic rocks on nearby Deception Island. This correlation can furnish new data about the age of the intemediate and lower tephra levels, and provides a great opportunity to improve our knowledge of ice age, mass balance and ice kinematics.

\section{CONCLUDING REMARKS}

The tested portable drilling machine for ice has proven to be a useful tool for obtaining short ice cores in a wide range of outcropping conditions reasonably easily. We especially recommend its use for sampling ice containing thin layers in outcrops where we can only observe apparent dips.

Despite the obvious core length limitation $(40-45 \mathrm{~cm})$, this device has proven to be very efficient in the study of recent volcanic ash levels (20-200 BP) interlayered in the Livingston ice sheets. This can contribute to the study of tephra layers and related volcanic events in the Antarctic, which has recently been revealed as a major goal (Smellie, in press). Information derived from ice-confined tephra is very precise and can complement data obtained from other continental or marine sedimentary archives in order to evaluate recent volcanic activity.

\section{ACKNOWLEDGEMENTS}

This work is included in the CICYT ANT93-0852 and 960734 projects. We are indebted to the crew of the Spanish Antarctic Station and other expedition members for their support. Detailed comments by E. Blake, which improved the original version of the manuscript, are also acknowledged.

\section{REFERENCES}

Calvet, J., R. Pallàs, F. Sàbat and J. M. Vilaplana. 1993. Los niveles de cenizas de los glaciares de Livingston. Criterios para su datación. In Serrat, D., ed. Quinto Simposio Español de Estudios Antárticos, 1993, Barcelona. Actas. Madrid, Comisión Interministerial de Ciencia y Tecnología, 195-208.

Pourchet, M., G. Furdada andJ. Corbera. 1996. Determinación del ${ }^{137}$ Cs en sondeos de hielo para el estudio del balance de masa del Glaciar Hurd. In VI Simposio Español de Estudios Antárticos, 1996, Miaflores de la Sierra, Madrid. Resúmenes. Madrid, Comisión Interministerial de Ciencia y Tecnología, 66.

Smellie, J. L. In press. The upper Cenozoic tephra record in the south polar region: review. Quat. Sci. Rev. 